\title{
How Soil Bacterial Communities with Seasonal Variation Respond Differently to Long-Term Fertilization and Plastic Film Mulching
}

\author{
John Farmer ${ }^{1}$, Sean Schaeffer ${ }^{2}$, Bin Zhang', Tingting An¹, \\ Jiubo Pei ${ }^{1}$, Jie Zhuang ${ }^{2}$, Jingkuan Wang ${ }^{1 *}$ \\ ${ }^{1}$ College of Land and Environment, Shenyang Agricultural University, Shenyang, China \\ ${ }^{2}$ Department of Biosystems Engineering and Soil Science, University of Tennessee, Knoxville, USA
}

Received: 18 July 2017

Accepted: 9 September 2017

\begin{abstract}
Although the fertilization effect on soil microbial communities have been studied extensively, its influence combined with plastic-film mulching on seasonal variations of bacterial communities remains unknown. High throughput sequencing was used to explore seasonal bacterial communities in a longterm fertilization experiment that commenced in 1987. Non-fertilization and the application of manure combined with nitrogen fertilization significantly $(\mathrm{P}<0.05)$ increased bacterial abundance at phylum level without film mulching in July and with film mulching in October. Also, the relative abundance of dominant bacterial groups in October exceeded those in July. Nitrogen fertilization (N) significantly $(\mathrm{P}<0.05)$ decreased soil bacterial diversity and richness with or without film mulching compared to nonfertilization controls during July and October. Plastic film mulching and long-term manure fertilization significantly $(\mathrm{P}<0.05)$ increased bacterial diversity and richness as well as the relative abundance of dominant bacterial groups. Statistical analysis revealed that soil $\mathrm{pH}$ was the main driving force influencing bacterial groups. In conclusion, our results highlight the relative importance of long-term application of manure fertilization and plastic film mulching on seasonal variations of bacterial diversity and structure. This finding also highlights the relevance of soil $\mathrm{pH}$ as the main deterministic abiotic factor for soil bacterial community structure regardless of film mulching.
\end{abstract}

Keywords: bacterial diversity, long-term fertilization, plastic film mulching, bacterial phyla, 16S rRNA gene

*e-mail: j-kwang@163.com 


\section{Introduction}

Environmental changes caused by human-related factors such as tillage, fertilizer application, crop rotation, and seasonal variations significantly affect soil microorganisms, leading to dynamic changes in microbial activity, abundance, diversity, and composition [1]. Studies have shown that seasonal variations influence soil microbial composition in many agroecosystems [2-3].

Although the application of chemical fertilizers to agricultural soils significantly improves crop yield and mitigates global food shortages [4], long-term application of chemical fertilizers on soils has led to serious consequences for the environment as well as soil microorganisms [5]. Studies have indicated that the longterm application of nitrogen fertilizer causes significant soil acidification due to low soil $\mathrm{pH}$ [6-7]. Agricultural practices such as manure fertilization and plastic film mulching are significant measures that ameliorate the deleterious effects of nitrogen fertilization. Cultivation with plastic film mulching substantially increases maize yield, which is vital to meet the consumption requirements of a growing population in developing countries like China [8-9]. This increase in productivity will be difficult to achieve under impoverished soil conditions $[8,10]$, hence the coupling effect of manure fertilization and film mulching is vital. Many studies have indicated that the use of manure fertilization with film mulching causes a significant increase in soil fertility and maize biomass productivity [9], enzyme activities [11], and microbial diversity [12].

Soil microorganisms are abundant and diverse and a majority of them are yet to be recovered [13]. Soil microbes play a significant role in maintaining soil functions, such as bioremediation, cycling of nutrients [14], plant health [15] and disease suppression activities [16]. Hence, maintaining high populations and microbial diversity in arable soils may be essential for agricultural sustainability [17]. Natural disturbances and human activities such as urban expansion, chemical fertilization, tillage, etc. have negative impacts on soil microbes, leading to loss of soil biodiversity [1819]. Actually, the long-term application of chemical fertilization often leads to loss of soil microbial diversity [20].

Plastic film mulching significantly increases the populations of soil bacteria, actinomycetes, and fungi [21], but their proportions can increase in different stages of plant growth [11, 22]. In addition, plastic film mulching increases the number of nitrogen fixing and denitrifying bacteria significantly, hence increasing maize maturity period and fertility of soil [23]. A study by Hou et al. [12] reported that the application of plastic film mulching and fertilization reduced the microbial carbon source utilization rate as well as microbial richness.

The amendment of livestock manure (particularly pig manure) has led to the proliferation of bacterial diversity, no matter whether they were used alone or in combination with chemical fertilizer [24-25]. Contrary to these findings, our previous research [7] showed that combined manure (pig manure) and nitrogen fertilization significantly reduced soil bacterial diversity, as well as the abundance of dominant bacterial phyla. According to a recent study by Sun et al. [26], microorganisms inhabiting plant residues and livestock manures can represent newly arrived immigrants that will likely affect the indigenous soil microbial community. Even though livestock manures contain much more bacteria, most of these bacteria are unable to compete with indigenous soil bacteria and hence do not play a significant role in increasing bacterial diversity and abundance [26-27].

A study revealed that tundra microbial communities varied greatly due to seasonal conditions and nutritional status of the soil, and thus the microbes were functionally adapted to those environmental changes [28]. Yao et al. [29] indicated that seasonal variations of soil microbial biomass and activity regulate plant growth. Soil microbial biomass and DNA contents were higher in summer than in spring, and also were influenced by the type of fertilizer applied to the soil [30].

Many studies have reported the long-term effect of plastic film mulching and fertilization on bacterial communities by DNA fingerprint techniques such as denaturing gel gradient electrophoresis (DGGE), TRLFP, PLFA, singer cloning, etc. To date, only a few studies have reported the seasonal variations of bacterial communities influence by fertilization and plastic film mulching application by Illumina Hiseq sequencing.

In this study, we describe a comparative analysis of bacterial communities in soils that have been subjected to 28 years of non-fertilization control (CK), nitrogen fertilization $(\mathrm{N})$, nitrogen fertilization amended with pig manure (MN), and manure (pig manure) fertilization (M) with or without plastic film mulching. This experiment was designed to unravel the significance of pig manure and plastic film mulching in alleviating the deleterious long-term effect of chemical nitrogen fertilization on soil bacterial communities. We used high-throughput sequencing of the $16 \mathrm{~S}$ ribosomal RNA (rRNA) encoding gene to explore the changes in soil bacterial communities and the relationship with soil properties in different fertilization regimes and nonfertilization control treatments with or without film mulching application during summer and autumn seasons, respectively. The main objectives of this study were: 1) to compare the differences and similarities of bacterial communities under plastic film mulching and fertilization during July and October periods and 2) to determine which environmental factors are important in shaping the bacterial community structure. We hypothesized that plastic film mulching and manure fertilization would increase and shape the bacterial community structure. Also, soil $\mathrm{pH}$ would be the main 
driving force shaping the major bacterial groups during the two seasons (summer and autumn).

\section{Materials and Methods}

\section{Study Site and Experimental Design}

This study was conducted on a plastic film mulching and fertilization experimental site initiated in 1987 at Shenyang Agricultural University $\left(41^{\circ} 49^{\prime} \mathrm{N}, 123^{\circ} 34^{\prime} \mathrm{E}\right)$, Liaoning Province, China. The site has a typical continental monsoon climate with mean annual air temperature of $7.9^{\circ} \mathrm{C}$ and mean annual precipitation of $705 \mathrm{~mm}$. The soil is classified as a Hapli-Udic Cambisol (FAO Classification), which is typical in northeastern China. At the beginning of the experiment, the soil had a $\mathrm{pH}\left(\mathrm{H}_{2} \mathrm{O}\right)$ value of 6.39 , SOC of $9.05 \mathrm{~g} \mathrm{~kg}^{-1}$, total nitrogen $(\mathrm{N})$ of $1.00 \mathrm{~g} \mathrm{~kg}^{-1}$, total phosphorus $(\mathrm{P})$ of $0.5 \mathrm{~g} \mathrm{~kg}^{-1}$, alkali-hydrolyzable $\mathrm{N}$ of $67.4 \mathrm{mg} \mathrm{kg}^{-1}$, available $\mathrm{P}$ of $8.4 \mathrm{mg} \mathrm{kg}^{-1}$, and a texture of $167 \mathrm{~g}$ sand $\mathrm{kg}^{-1}, 584 \mathrm{~g}$ silt $\mathrm{kg}^{-1}$, and $249 \mathrm{~g}$ clay $\mathrm{kg}^{-1}$ at $0-20 \mathrm{~cm}$ depth [31].

The experiment was a randomized split-plot design with three replicates. The whole plot treatments were with or without plastic film mulching $(\mathrm{P})$, while the subplot treatments included no fertilizer (CK), chemical $\mathrm{N}$ fertilizer (135 kg N ha-1 $\left.\mathrm{y}^{-1}, \mathrm{~N}\right)$, pig manure (135 kg N $\left.\mathrm{ha}^{-1} \mathrm{y}^{-1}, \mathrm{M}\right)$, and pig manure combined with chemical $\mathrm{N}$ fertilizer $\left(67.5 \mathrm{~kg} \mathrm{~N} \mathrm{ha}^{-1} \mathrm{y}^{-1}\right.$ from manure and $67.5 \mathrm{~kg} \mathrm{~N}$ $\mathrm{ha}^{-1} \mathrm{y}^{-1}$ from $\mathrm{N}$ fertilizer, $\mathrm{MN}$ ). The area of each subplot was $69 \mathrm{~m}^{2}$.

P-CK, P-N, P-M, and P-MN ( $\mathrm{P}=$ plastic film mulching) were designated as treatments with plastic film mulching, while $\mathrm{CK}, \mathrm{N}, \mathrm{M}$, and $\mathrm{MN}$ were treatments without mulching. Chemical $\mathrm{N}$ fertilizer was applied as urea before sowing. The pig manure contained $150 \mathrm{~g} \mathrm{~kg}^{-1}$ of total organic C, $10 \mathrm{~g} \mathrm{~kg}^{-1}$ of total $\mathrm{N}, 10 \mathrm{~g}$ $\mathrm{kg}^{-1}$ of P2O5, and $4 \mathrm{~g} \mathrm{~kg}^{-1}$ of $\mathrm{K} 2 \mathrm{O}$ on a dry weight basis and was basally applied. Maize was planted in May at a rate of 58,000 seeds $\mathrm{ha}^{-1}$ in $60 \mathrm{~cm}$ row width and harvested in October. The crop residues were removed from the field plots annually as per current practices [3233]. Commercially available plastic film (PVC) mulch was placed into respective plots and spread by hand raking. Weeds were constantly removed from the plots by hand on a periodic basis.

\section{Soil Sampling}

Soil samples were randomly collected from each subplot with soil augers (3 cm diameter) from $0-20 \mathrm{~cm}$ depth in July (summer) and October (autumn) 2014. The three replicate soil cores were obtained within a $150 \mathrm{~cm}^{2}$ area per plot but processed separately to assess within- and between-plot variation. The fresh soil cores were immediately placed on ice and transported to the laboratory. Soil samples were sieved by passing through an automatic sieve machine with a $2 \mathrm{~mm}$ mesh at a speed of 1.5 for 2 minutes to remove debris, while roots were removed with forceps. Soil samples were stored at room temperature for the analysis of physico-chemical properties, and at $-80^{\circ} \mathrm{C}$ for molecular analysis.

\section{Soil DNA Extraction PCR Amplification}

Total genomic soil DNA was extracted from $0.5 \mathrm{~g}$ of soil using a MOBIO-PowerSoil DNA Isolation Kit (MOBIO Laboratories, Inc., Carlsbad, CA) according to the manufacturer's protocol. Soil DNA concentration was checked on Nanodrop 2000 and monitored on 1\% agarose gel electrophoresis. PCR product was purified with a Qiagen Gel Extraction Kit (Qiagen, Germany).

Bacterial communities were amplified based on V4-V5 hypervariable region of the 16S rRNA gene with primers $515 \mathrm{~F}$ and $907 \mathrm{R}$. The sequences of the adapters are shown in italics and are underlined, and Ns represent the 6-mer barcode sequence. All PCR reactions were carried out in $30 \mu \mathrm{L}$ reactions with $15 \mu \mathrm{L}$ of Phusion High-Fidelity PCR Master Mix (New England Biolabs); $0.2 \mu \mathrm{M}$ of forward and reverse primers, and about 10 ng DNA template. Thermal cycling consisted of initial denaturation at $98^{\circ} \mathrm{C}$ for $1 \mathrm{~min}$, followed by 30 cycles of denaturation at $98^{\circ} \mathrm{C}$ for $10 \mathrm{~s}$, annealing at $50^{\circ} \mathrm{C}$ for $30 \mathrm{~s}$, elongation at $72^{\circ} \mathrm{C}$ for $30 \mathrm{~s}$, and finally at $72^{\circ} \mathrm{C}$ for $5 \mathrm{~min}$.

\section{Soil Illumina HiSeq Platform}

Equal volume of $1 \mathrm{X}$ loading buffer (contained SYB green) was mixed with PCR products on $2 \%$ agarose gel (electrophoresis) for the detection of bright bands. Samples with bright bands strip between 400-450 bp were chosen for subsequent experiments. PCR products were mixed in equidensity ratios and then the mixture of PCR products was purified with a GeneJET Gel Extraction Kit (Thermo Scientific). Sequencing libraries were generated using NEB Next Ultra DNA Library Prep Kit for Illumina (NEB, USA) following the manufacturer's recommendations, and index codes were added. The library quality was assessed on the Qubit@2.0 Fluorometer (Thermo Scientific) and Agilent Bioanalyzer 2100 system. Finally, the library was sequenced on an Illumina HiSeq platform and $250 \mathrm{bp}$ paired-end reads were generated at Novogene Company, Beijing, China, according to standard protocols.

\section{Processing of Sequencing Data Analysis}

Paired-end reads from soil DNA fragments were merged by using FLASH [34]. Paired-end reads was assigned to each sample according to unique barcodes. Sequences were processed using a QIIME software package [35]. First, reads were filtered by QIIME quality filters [36] and tags were compared with the reference database using the UCHIME algorithm [37] to detect chimeric sequences, and these chimeric sequences were 
removed by using UCLUST software [38]. Then we used pick_de_novo_otus.py to pick operational taxonomic units (OTUs) and generate an OTU table. Sequencing analysis was performed by Uparse v7.0.1001 software [39], and sequences with $\geq 97 \%$ similarity were assigned to the same OTU. We picked a representative sequence for each OTU against the GreenGene database [40], and used the RDP classifier [36] to annotate taxonomic information for each representative sequence. In order to study the phylogenetic relationships of different OTUs, and the difference of the dominant species in different samples, multiple sequence alignments were conducted using MUSCLE software v3.8.31 [41]. OTU abundance information was normalized using a standard of sequence number corresponding to the sample with the least sequence.

\section{Statistical Analysis}

Alpha diversity (Shannon, Simpson, Chaol, and ACE) metrics were calculated using MOTHUR software [42]. Principal coordinates analysis (PCoA) was performed using the beta_diversity_through_plots. py script in the QIIME pipeline [43]. SPSS for windows (version 19) was used to test for significance $(\mathrm{P}<0.05)$ using Pearson correlation coefficient between treatments of soil properties and bacterial diversity; and analysis of variance (ANNOVA) to test for significance $(\mathrm{P}<0.05)$ between relative abundances and alpha diversity of soil bacterial communities using Duncan post-hoc test at 95\% confidence level.

\section{Results and Discussion}

\section{Seasonal Variations on Soil Bacterial Community Diversity under Long-Term Fertilization}

Fig. SS 1 shows that all the treatments with or without plastic film mulching for July and October periods reached a plateau, implying that the sequence depth generated in this study was enough to be classified into various taxonomic levels. At a $90 \%$ similarity level, soil bacteria from 16 samples each for July and October with and without mulching were mainly clustered together by replicate treatment, and replicate treatments with film mulching were distinctively separated from those without film mulching (Fig. SS 2). Similarly, the PCoA analysis (Figs 1a,b) showed that replicate treatments clustered together within the same coordinate irrespective of their mulching status and were clearly separated by the second principal coordinate (P2) for July and October. As shown in Figs 1(a-b), the two main axes (P1 and P2) explained $\sim 24 \%$ and $\sim 30 \%$ of the observed variance in total for July and October, respectively. These results are consistent with other findings in which treatments mainly clustered together based on mulching and fertilization [7, 26, 44].

Alpha diversity indices were used to investigate the effect of long-term fertilization on bacterial community diversity (Shannon index) and richness (Chaol and ACE indices) for July and October, respectively (Table 3). Microbial diversity is often considered as a measure of soil quality and soil health

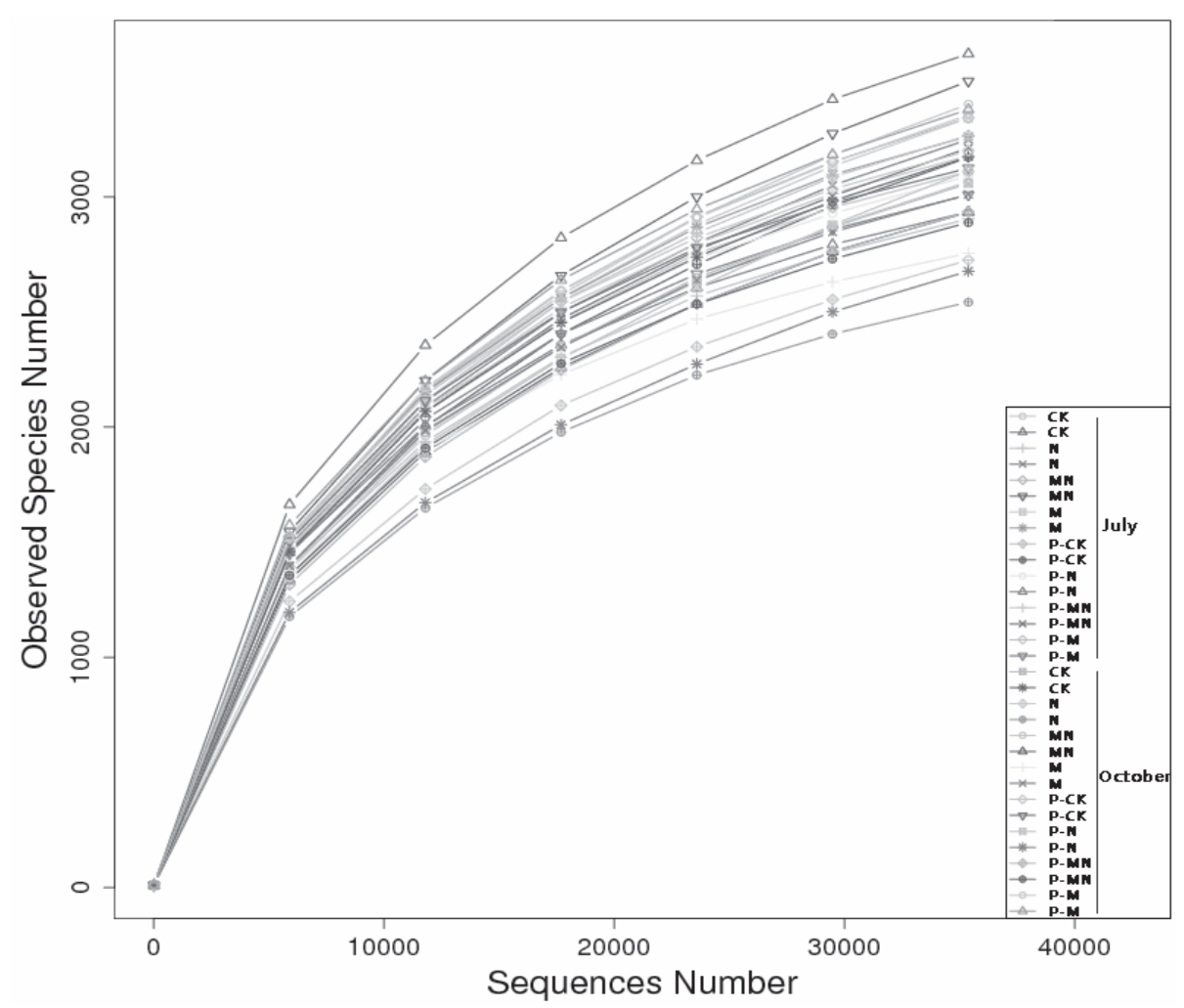

Fig. SS1. The observed OTUs of soil bacteria against numbers of sequences for July and October with and without film mulching. 
a)

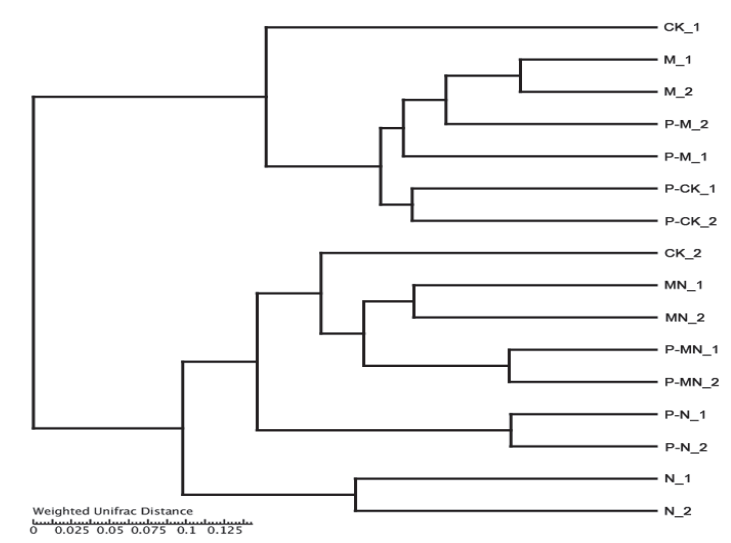

b)

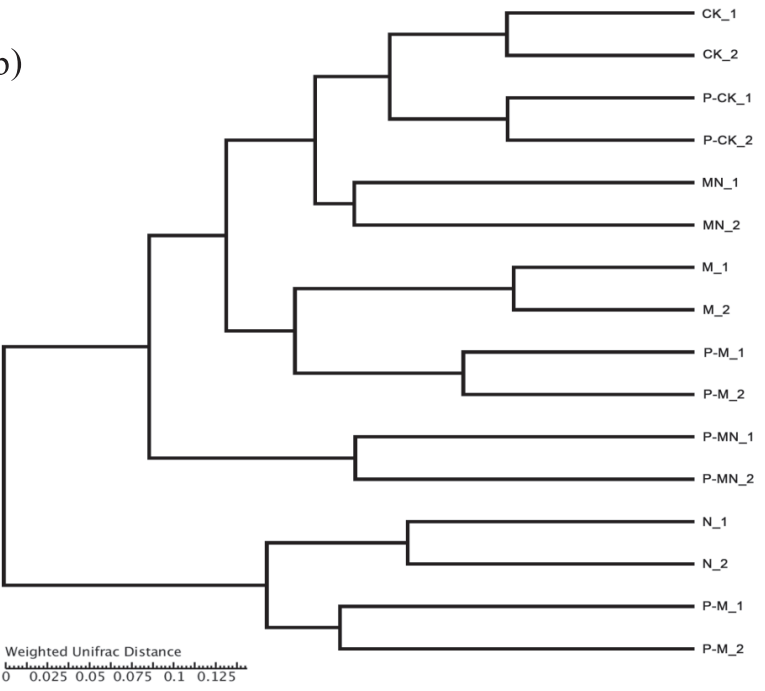

Fig. SS2. The soil bacterial community structure of fertilized and non-fertilized control for July a) and October b).

indicator [19]. The Shannon diversity in non-fertilization (CK) treatments were significantly $(\mathrm{P}<0.05)$ higher than in nitrogen fertilization treatments for July and October. With the exception of July, it was significantly $(\mathrm{P}<0.05)$ greater in treatments under plastic film mulching compared to those without film mulching for October. The main reason might be that treatments with film mulching play little or no role in increasing soil bacterial diversity in summer (July), because this region usually has hot weather and often experiences more arid conditions in summer (July) than in autumn (September), when there is precipitation with a cool climate. Therefore, we concluded in this study that soil bacterial diversity dynamics is unstable and thus seasonal variation is one of the factors that influences soil microbes.

Long-term application of manure fertilizer significantly increased soil bacterial diversity compared to other fertilization treatments (Table 3), similar to our previous research [7], probably due to the same soil type and fertilization treatments used, though the year and season of sample collection was different. The main difference between the previous study [7] and this present study is that combined manure and

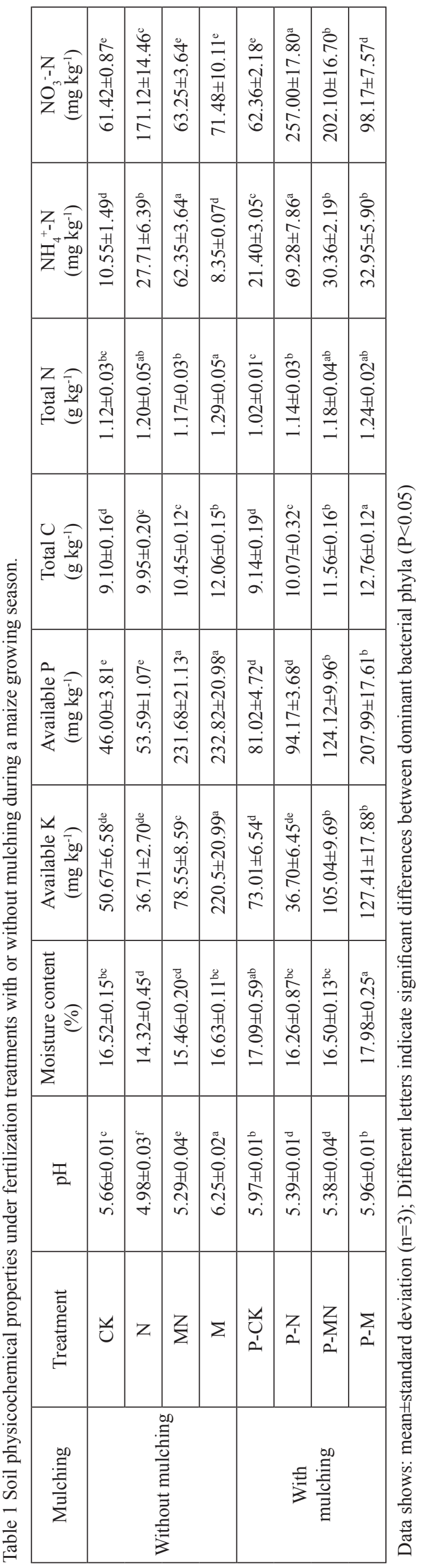


Table 2. The average maize yield of different treatments $\left(\mathrm{t} \mathrm{ha}^{-1}\right)$.

\begin{tabular}{|c|c|c|c|c|c|c|c|c|}
\hline Treatment & $\mathrm{CK}$ & $\mathrm{N}$ & $\mathrm{M}$ & $\mathrm{MN}$ & P-CK & P-N & P-MN & P-M \\
\hline $\begin{array}{c}\text { Maize total } \\
\text { biomass }\end{array}$ & $11.28 \pm 1.29 \mathrm{c}$ & $13.33 \pm 1.82 \mathrm{c}$ & $16.98 \pm 2.03 \mathrm{ab}$ & $17.07 \pm 2.60 \mathrm{ab}$ & $11.14 \pm 1.95 \mathrm{c}$ & $15.61 \pm 2.46 \mathrm{~b}$ & $18.71 \pm 3.05 \mathrm{a}$ & $19.08 \pm 2.42 \mathrm{a}$ \\
\hline Maize yield & $3.82 \pm 1.01 \mathrm{f}$ & $5.61 \pm 1.00 \mathrm{de}$ & $7.10 \pm 1.34 \mathrm{abc}$ & $6.77 \pm 1.32 \mathrm{bcd}$ & $4.35 \pm 1.03 \mathrm{ef}$ & $6.64 \pm 1.38 \mathrm{dc}$ & $8.20 \pm 1.81 \mathrm{a}$ & $8.06 \pm 1.54 \mathrm{ab}$ \\
\hline
\end{tabular}

Note: P means plastic film mulching. Data indicate average yield/total maize biomass (2004-2013). Different letter indicate significant differences among different treatments $(\mathrm{P}<0.05)$

nitrogen fertilization (MN) significantly $(\mathrm{P}<0.05)$ reduced bacterial diversity, while in the present study nitrogen fertilization greatly reduced bacterial diversity. Therefore, long-term application of nitrogen fertilization whether amended or not had a profound effect on soil bacterial diversity. A study indicated that the longterm application of nitrogen fertilization significantly reduced bacterial diversity when compared with nonfertilization controls [26]. Another study confirmed that the long-term application of nitrogen fertilization caused soil acidification, which led to a significant $(\mathrm{P}<0.05)$ reduction of bacterial diversity and richness [5]. Contrary to our findings, research has shown that long-term fertilization - especially nitrogen fertilization amended with manure - significantly $(\mathrm{P}<0.05)$ increased
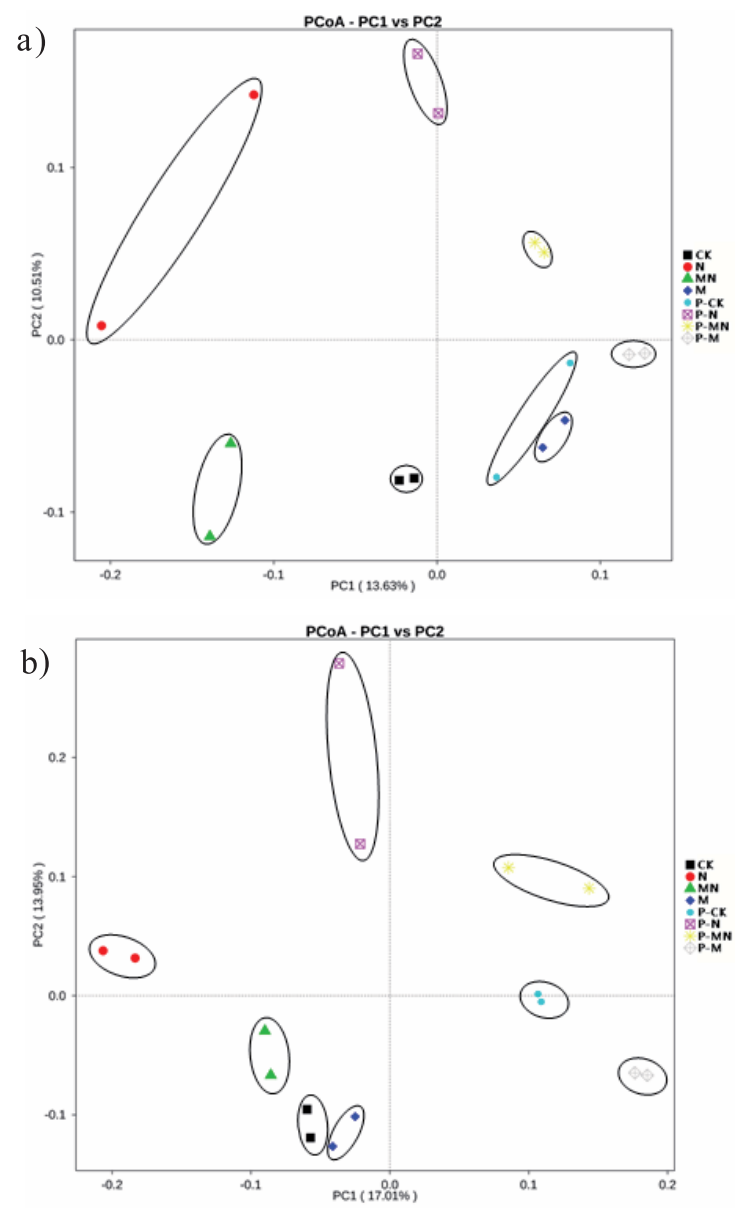

Fig. 1. The PCoA of fertilized and non-fertilized treatments with or without film mulching a) July and b) October. soil microbial diversity [45-46]. A plausible explanation might be that this results from the use of film mulching or the amount of fertilizer used. Long-term fertilization of manure plays an important role in increasing bacterial OTUs, diversity, and richness of soils.

The ACE and chaol indices measuring bacterial richness displayed similar results to diversity of soil bacteria with or without film mulching for July and October. Also, the observed OTUs were similar to bacterial diversity and richness, though manure fertilization with film mulching was highly significant $(\mathrm{P}<0.05)$ compared to other treatments for October. The coverages were enough for sequences to be classified into various taxonomic groups (Table 3 ).

\section{Seasonal Variations on Soil Microbial Composition}

We saw a total of 849,868 and 940,986 clean sequences for July and October, respectively, with each sample having more than 40,000 sequences after filtering the sequences for quality scores, chimeras, and sequencing errors, and also a total of 51,610 and 47,946 OTUs were obtained for July and October, respectively, and classified into various taxonomic levels using the RDP classifier with $90 \%$ confidence rating as against the Greengenes database. The sequences that were not classified into any specific taxonomic bacterial phyla were categorized as 'others' and accounted for $8.43 \%$ and $7 \%$ for July and October, respectively. The relative abundance of dominant bacteria phyla for July and October are shown in Figs 2(a-b). The relative abundance of the top 10 bacterial phyla for all samples (with or without plastic film mulching) included: Proteobacteria (45.81\%)/(48.25\%), Acidobacteria (15.37\%)/(12.39\%), Actinobacteria (8.73\%)/(10.36\%), Gemmatimonadetes (5.38\%)/(5.28\%), Verrucomicrobia $\quad(4.42 \%) /(3.51 \%)$, Crenarchaeota $(3.96 \%) / 4.84 \%)$, Planctomycetes $(3.07 \%) /$ (3.06\%), Bacteroidetes $(2.22 \%) /(3.38 \%)$, Firmicutes $(2.04 \%) /(1.19 \%)$, and WPS-2 $(0.56 \%) /(0.74 \%)$ for July and October, respectively (Figs 2a-b). Proteobacteria was the most abundant bacterial phyla was found in all samples with or without plastic film mulching. Most of these bacteria are ubiquitous in agricultural soil habitats [7, 47-49]. Consistent with research conducted by Sun et al. [26], Proteobacteria, Actinobacteria, and Acidobacteria were the three most dominant bacterial phyla, accounting for more than $69 \%$ of relative 
Table 3. Alpha diversity indices of soil bacterial communities of fertilized and non-fertilized treatments for July and October with or with film mulching.

\begin{tabular}{|c|c|c|c|c|c|c|}
\hline Mulching & Treatment & Observed OTUs & Shannon index & ACE index & Chao1 index & Coverage \\
\hline \multicolumn{7}{|c|}{ July } \\
\hline \multirow{4}{*}{$\begin{array}{l}\text { Without } \\
\text { mulching }\end{array}$} & $\mathrm{CK}$ & $3512.67 \pm 63.22^{\mathrm{a}}$ & $9.52 \pm 0.15^{\mathrm{a}}$ & $4689.25 \pm 52.97^{\mathrm{a}}$ & $4501.43 \pm 143.10^{\mathrm{a}}$ & $0.97^{\mathrm{c}}$ \\
\hline & $\mathrm{N}$ & $3077.67 \pm 99.59^{\mathrm{de}}$ & $9.19 \pm 0.08^{\mathrm{bc}}$ & $3958.78 \pm 230.69^{\mathrm{cd}}$ & $3894.70 \pm 263.14^{\text {bcd }}$ & $0.97^{\mathrm{ab}}$ \\
\hline & $\mathrm{MN}$ & $3423.67 \pm 45.90^{\mathrm{ab}}$ & $9.33 \pm 0.01^{\mathrm{ab}}$ & $4548.06 \pm 175.36^{\mathrm{ab}}$ & $4418.95 \pm 252.49^{\mathrm{ab}}$ & $0.97^{\mathrm{bc}}$ \\
\hline & M & $3303.67 \pm 22.81^{\mathrm{bc}}$ & $9.35 \pm 0.00^{\mathrm{ab}}$ & $4303.59 \pm 144.28^{\mathrm{abc}}$ & $4152.59 \pm 213.94^{\mathrm{abc}}$ & $0.97^{\mathrm{bc}}$ \\
\hline \multirow{4}{*}{$\begin{array}{c}\text { With } \\
\text { mulching }\end{array}$} & P-CK & $3219.67 \pm 27.42^{\mathrm{cd}}$ & $9.03 \pm 0.06^{\mathrm{c}}$ & $4310.01 \pm 86.05^{\mathrm{abc}}$ & $4151.88 \pm 168.08^{\mathrm{abc}}$ & $0.97^{\mathrm{bc}}$ \\
\hline & $\mathrm{P}-\mathrm{N}$ & $3013.00 \pm 45.03^{\mathrm{e}}$ & $9.39 \pm 0.01^{\mathrm{ab}}$ & $3671.05 \pm 66.78^{\mathrm{d}}$ & $3502.98 \pm 22.63^{\mathrm{d}}$ & $0.98^{\mathrm{a}}$ \\
\hline & P-MN & $3196.00 \pm 9.81^{\mathrm{cd}}$ & $9.35 \pm 0.03^{\mathrm{ab}}$ & $4172.54 \pm 129.12^{\mathrm{bc}}$ & $4106.70 \pm 171.93^{\mathrm{abc}}$ & $0.97^{\mathrm{bc}}$ \\
\hline & P-M & $3059.67 \pm 29.16^{\text {de }}$ & $9.22 \pm 0.00^{\mathrm{bc}}$ & $3703.19 \pm 47.61^{\mathrm{d}}$ & $3583.21 \pm 22.28^{\mathrm{cd}}$ & $0.98^{\mathrm{a}}$ \\
\hline \multicolumn{7}{|c|}{ October } \\
\hline \multirow{4}{*}{$\begin{array}{l}\text { Without } \\
\text { Mulching }\end{array}$} & CK & $3116.67 \pm 33.20^{\mathrm{b}}$ & $9.11 \pm 0.06^{b}$ & $4171.51 \pm 37.27^{\mathrm{ab}}$ & $4146.54 \pm 14.63^{b}$ & $0.97^{\mathrm{bcd}}$ \\
\hline & $\mathrm{N}$ & $2634.67 \pm 52.83^{\mathrm{d}}$ & $8.66 \pm 0.07^{\mathrm{c}}$ & $3448.12 \pm 152.77^{\mathrm{c}}$ & $3288.77 \pm 199.14^{b}$ & $0.98^{\mathrm{a}}$ \\
\hline & $\mathrm{MN}$ & $3000.00 \pm 38.11^{\mathrm{bc}}$ & $8.90 \pm 0.11^{\mathrm{b}}$ & $4094.12 \pm 82.44^{\mathrm{ab}}$ & $4038.16 \pm 41.19^{b}$ & $0.97^{\mathrm{bc}}$ \\
\hline & M & $2883.00 \pm 73.90^{\mathrm{c}}$ & $9.04 \pm 0.03^{b}$ & $3515.04 \pm 152.59^{\mathrm{c}}$ & $3374.29 \pm 108.28^{b}$ & $0.98^{\mathrm{a}}$ \\
\hline \multirow{4}{*}{$\begin{array}{c}\text { With } \\
\text { mulching }\end{array}$} & P-CK & $3163.00 \pm 21.94^{b}$ & $9.35 \pm 0.00^{\mathrm{a}}$ & $3864.60 \pm 60.85^{\mathrm{bc}}$ & $3760.40 \pm 76.36^{\mathrm{b}}$ & $0.98^{\mathrm{a}}$ \\
\hline & $\mathrm{P}-\mathrm{N}$ & $2896.00 \pm 125.86^{\mathrm{c}}$ & $8.92 \pm 0.10^{\mathrm{b}}$ & $4526.24 \pm 336.14^{\mathrm{a}}$ & $5688.77 \pm 1063.43^{\mathrm{a}}$ & $0.97^{\mathrm{d}}$ \\
\hline & P-MN & $2912.00 \pm 13.28^{\mathrm{b}}$ & $8.92 \pm 0.00^{\mathrm{b}}$ & $3766.43 \pm 114.44^{\mathrm{bc}}$ & $3648.85 \pm 126.36^{\mathrm{b}}$ & $0.98^{\mathrm{d}}$ \\
\hline & P-M & $3368.00 \pm 6.93^{\mathrm{a}}$ & $9.34 \pm 0.09^{\mathrm{a}}$ & $4403.60 \pm 10.59^{\mathrm{a}}$ & $4229.11 \pm 32.43^{b}$ & $0.97^{\mathrm{b}}$ \\
\hline
\end{tabular}

Data shows: mean \pm standard deviation $(\mathrm{n}=3)$; Different letters indicate significant differences between dominant bacterial phyla $(\mathrm{P}<0.05)$.

abundances of the soil bacterial communities of our experimental site.

The relative abundance of Proteobacteria was highly significantly greater $(\mathrm{P}<0.05)$ in combined manure and nitrogen fertilization treatments (P-MN 50.82\%) for July without film mulching and with mulching (P-MN $56.93 \%$ ) in October, respectively, compared to other fertilized and non-fertilized treatments. Proteobacteria was also significantly $(\mathrm{P}<0.05)$ abundant in nonfertilized treatment (CK) and nitrogen fertilization (N) without film mulching compared to other samples collected in July (Fig. 2a); while significantly greater $(\mathrm{P}<0.05)$ in manure fertilization treatments $(\mathrm{M})$ with and without film mulching compared to other fertilized and non-fertilized treatments for the period of October (Fig. 2b). Contrary to the present study, our previous findings [7] indicated that Proteobacteria were greatly reduced in combined manure and nitrogen fertilization (MN) compared to non-fertilization controls. In our previous study [7], samples were collected in September (autumn), and for the present study, samples were collected in July (Summer) and October (autumn), hence we confirmed that seasonal variations affect the relative abundances of this phylum in fertilized and non-fertilized treatments with or without film mulching. Acidobacteria was relatively significantly greater
$(\mathrm{P}<0.05)$ in manure $(\mathrm{M})$ fertilization and non-fertilized control $(\mathrm{CK})$ treatments with or without film mulching for July and October. The least relative abundances of Acidobacteria were found in nitrogen $(\mathrm{N})$ and combined manure and nitrogen (MN) fertilization treatments for July and October, respectively. Acidobacteria are usually characterized as oligotrophs and are known to dominate environments with low nutrient availability. However, Jones et al. [50] disputed that this may not be an accurate classification, while Naether et al. [51] indicated that some subgroups of Acidobacteria reacted differently to the nutrient requirement, suggesting that not all are oligotrophic. On the other hand, Actinobacteria was significantly greater $(\mathrm{P}<0.05)$ in nitrogen $(\mathrm{N})$ and combined manure and nitrogen (MN) fertilization for July and October, respectively, though their proportions in these treatments were higher during the October period. In a study conducted by Cederlund et al. [52], Actinobacteria were also the dominant phyla in nitrogen or nitrogen-amended soils, which implies that this phyla has a strong affinity for nitrogen. Crenarchaeota was significant $(\mathrm{P}<0.05)$ in non-fertilization control $(\mathrm{CK})$ treatments and manure fertilization treatments with and without plastic film mulching compared to other treatments for the period of July, and significant in non-fertilization treatment and combined manure and 

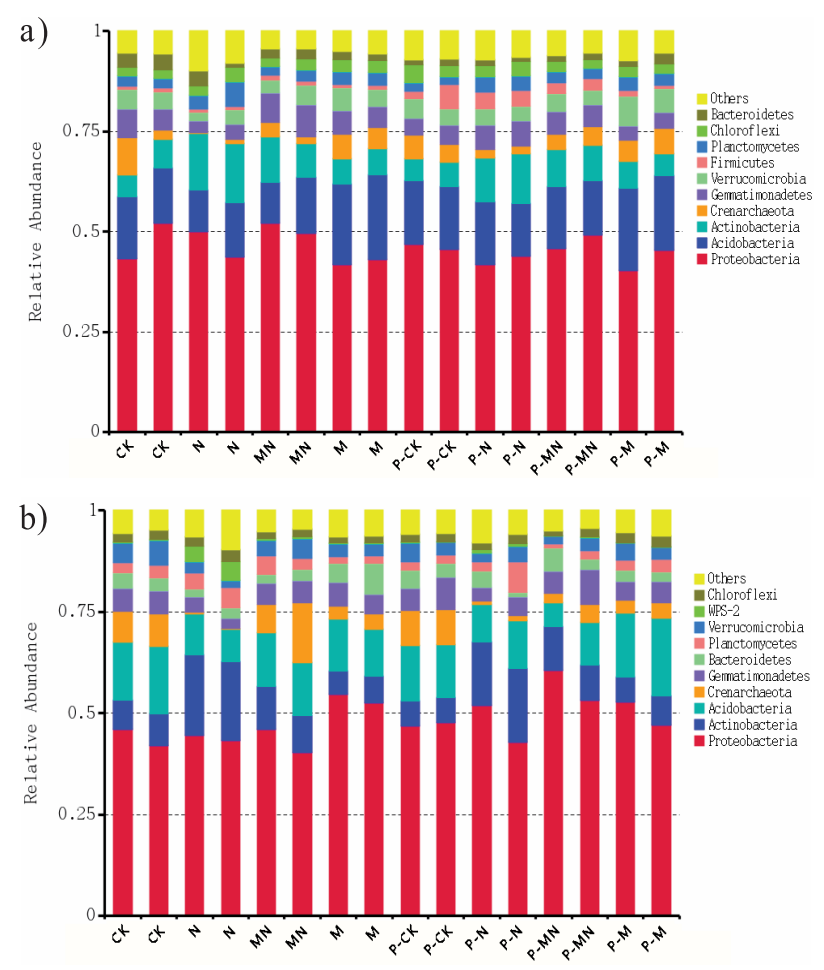

Fig. 2. Relative abundances of top ten bacterial phyla for a) July and b) October samples.

nitrogen fertilization treatment in October samples. The relative abundances of Crenarchaeota were greatly reduced in nitrogen fertilization treatments compared to the others. Gemmatimonadetes bacteria were highly significant $(\mathrm{P}<0.05)$ in combined manure and nitrogen fertilization without mulching in July and with mulching in October, though they were reduced greatly in nitrogen fertilization for both periods (July and October). The decrease in the relative abundance of Gemmatimonadetes in N-fertilized soils of this study contradicted the results of Nemergut et al. [52], showing that they may be less ecologically coherent in terms of their responses to N-fertilization. Another study also reported that Gemmatimonadetes are specifically adapted to dry environmental conditions [54].

Generally, the proportions of bacterial phyla were significantly $(\mathrm{P}<0.05)$ increased in samples collected in October than those in July with or without mulching. The plausible reason might be that July is usually hot with temperatures soaring up to $34^{\circ} \mathrm{C}$ in part of northeastern China. In other words, seasonal variations significantly $(\mathrm{P}<0.05)$ affected soil bacterial activity with or without film mulching.

\section{Maize Grain Yield}

Maize total biomass in Table 2 include root, shoot, and leaf biomasses. The application of organic manure single (M) or combined with nitrogen fertilizer (MN) under no-mulching increased the maize total biomass by an average of $38 \%$ compared with $\mathrm{CK}$ and $\mathrm{N}$ treatments
(Table 2). The same trend was found under mulching as under no-mulching. Mulching significantly enhanced the maize total biomass after the application of $\mathrm{N}$ fertilizer. Under no-mulching conditions, maize yield was $82 \%$ and $24 \%$ higher in organic treatments ( $\mathrm{MN}$ and $\mathrm{N}$ ) than in $\mathrm{CK}$ and $\mathrm{N}$ treatments, respectively. Under mulching conditions, it was almost 2 and 1.2 times in organic treatments ( $\mathrm{MN}$ and $\mathrm{N}$ ) compared with $\mathrm{CK}$ and $\mathrm{N}$ treatments, respectively. Similarly, manure fertilization, whether combined or not and irrespective of mulching, also significantly increased the relative abundances of bacterial communities at the phylum level. Studies have shown that nitrogen fertilization combined with manure significantly increased grain yield as well as some microbiological properties [1, 55]. This implied that the long-term application of manure (M) fertilization in the form of pig manure as well as combined manure and nitrogen fertilization (MN) are very good agricultural practices for increasing maize yield productivity in alleviating global food crisis. Consistent with our findings, Liu et al. [55] reported that manure fertilization treatment significantly increased maize yield productivity compared to the non-fertilization controls. However, contrary to this study, Masto et al. [56] indicated that nitrogen fertilization significantly $(\mathrm{P}<0.05)$ increased the wheat grain and maize stover yields compare to farmyard manure or its combination with nitrogen fertilization. The plausible cause in our study might be as a result of variations in climatic conditions or differences in the amount of fertilizer application.

\section{Relationship between Soil Bacterial Communities and Soil Physicochemical Properties}

The long-term application of nitrogen fertilization significantly $(\mathrm{P}<0.05)$ decrease soil $\mathrm{pH}$ compared to manure fertilization only and non-fertilization control (Table 1). In agreement with our results, studies have indicated that long-term nitrogen fertilization treatment - whether combined or not - considerably reduced soil $\mathrm{pH}[55,57]$. The decrease in soil $\mathrm{pH}$ in our study might be a result of nitrification and acidification processes stimulated by the long-term application of chemical nitrogen fertilizer [58]. The soil properties: $\mathrm{pH}, \mathrm{NH}+4-\mathrm{N}, \mathrm{NO} 3-\mathrm{-N}, \mathrm{SOC}$, moisture content, Total N, and available $\mathrm{K}$ and $\mathrm{P}$ had significant $(\mathrm{P}<0.05)$ influence on soil bacterial communities for July and October (Tables 4-5). Consistent with our findings, Tian et al. [59] reported that these soil properties had significant influence on dominant bacterial phyla. In this study, soil $\mathrm{pH}$ was the most significant abiotic factor that affected dominant bacterial phyla either positively or negatively during summer and autumn (Tables 4-5). Although several studies have also indicated that $\mathrm{pH}$ was the main driving force for shaping bacterial communities in agricultural soils $[1,26,60-63]$, the effect of soil physicochemical properties on bacterial groups was not affected by seasonal changes. 


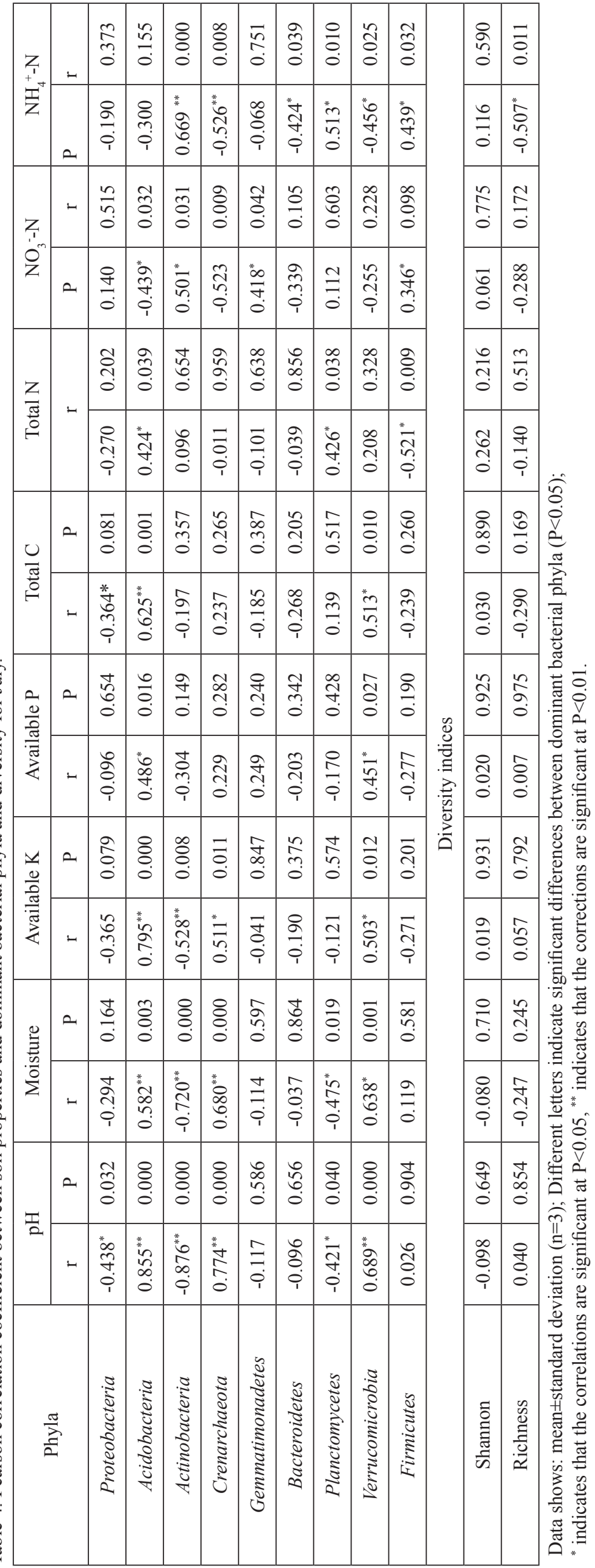




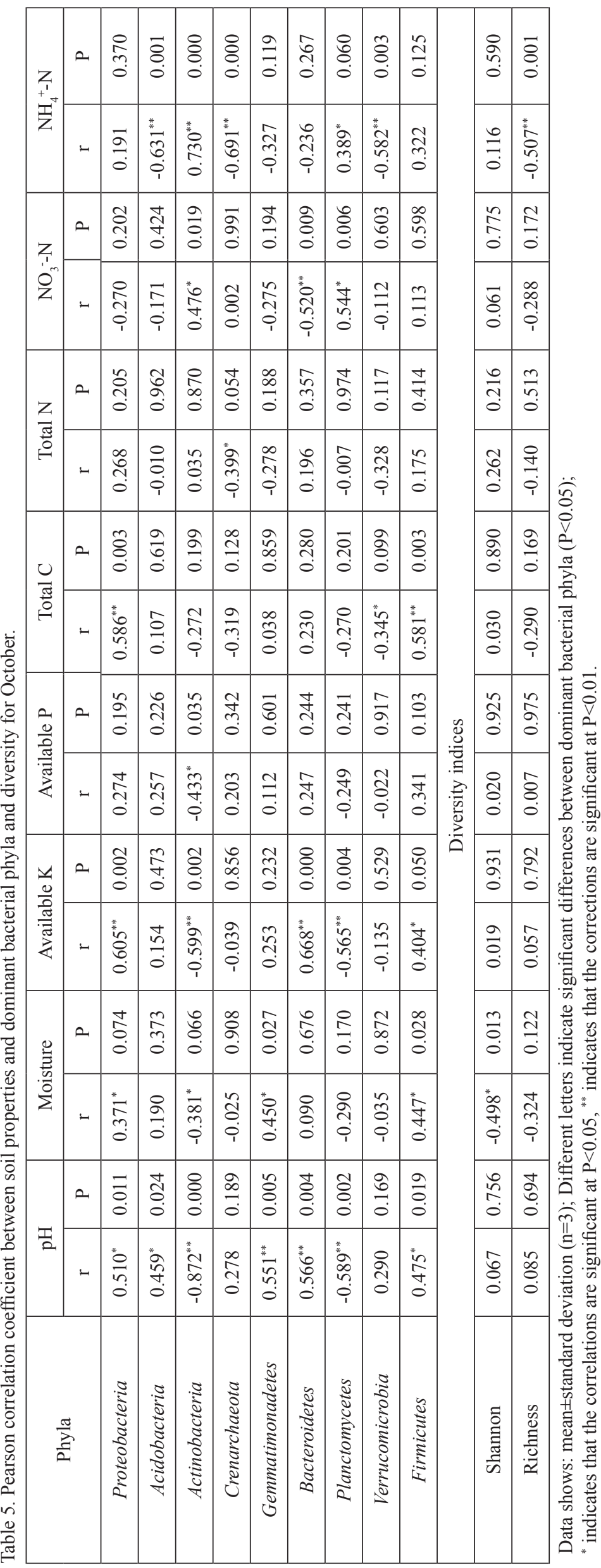




\section{Conclusions}

In this study, seasonal changes and long-term fertilizer application significantly $(\mathrm{P}<0.05)$ affected the dominant bacterial phyla. Contrary to our expectation pig manure (MN) whether amended with nitrogen fertilizer or not significantly $(\mathrm{P}<0.05)$ increased bacterial diversity and richness as well as the abundances of dominant bacterial phyla during the two seasons under film mulching. There was no distinct seasonal variation on the effect of soil physicochemical properties with bacterial phyla. During the two seasons, $\mathrm{pH}$ remained the dominant factor affecting dominant bacterial phyla. It is difficult to ascertain whether long-term application of pig manure amended with nitrogen fertilizer reduce bacterial diversity and abundance of dominant bacteria groups; hence, specifically designed experiments are required to determine the seasonal changes on soil bacterial diversity and abundance as affected by the long-term application of pig manure combined with nitrogen fertilizer.

\section{Acknowledgements}

This study is supported by the National Key R\&D Program of China (2017YFD0200604), by the National Natural Science Foundation of China (31330011) and by the "Strategic Priority Research Program-climate change: Carbon Budget and Relevant Issue" of the Chinese Academy of Sciences (XDA05050501).

\section{References}

1. ZHAO J., NI T., LI Y., XIONG W., RAN W., SHEN B., SHEN Q., ZHANG R. Responses of Bacterial Communities in Arable Soils in a Rice-Wheat Cropping System to Different Fertilizer Regimes and Sampling Times. PLoS One. 9, e85301, 2014.

2. KENNEDY N.M, GLEESON D.E, CONNOLLY J, CLIPSON N.J. Seasonal and management influences on bacterial community structure in an upland grassland soil. FEMS Microbiol Ecology. 53, 329, 2005.

3. HANNULA S.E., D.E BOER W., VAN VEEN J. A 3-year study reveals that plant growth stage, season and field site affect soil fungal communities while cultivar and GM-trait have minor effects. PLoS One 7, e33819, 2012.

4. SAVCI S. An agricultural pollutant: chemical fertilizer. International Journal of Environmental Science and Development. 3, 77, 2012.

5. ZHANG X., LIU W., ZHANG G., JIANG L., HAN $X$. Mechanisms of soil acidification reducing bacterial diversity. Soil Biology \& Biochemistry. 81, 275, 2015.

6. SCHRODER J.L., ZHANG H., GIRMA K., RAUN W.R., PENN C.J., PAYTON M.E. Soil acidification from longterm use of nitrogen fertilizers on winter wheat. Soil Science Society of America Journal. 75, 957, 2011.

7. FARMER J., ZHANG B., JIN X., ZHANG P., WANG J. Long-term effect of plastic film mulching and fertilization on bacterial communities in a brown soil revealed by high through-put sequencing. Archives of Agronomy and Soil Science. 1, 2016

8. WANG J., ZHANG J., XU X., ZHANG X., ZHU F. Effect of Plastic Film Mulching on soil fertility. Journal of Shenyang Agricultural University. 23, 32, 1992.

9. LI S., CAI Z., YANG H., WANG J. Effects of long-term fertilization and plastic film covering on some soil fertility and microbial properties. Acta Ecologica Sinica. 29, 2489, 2009.

10. ZHANG J., WANG J., XU X., TANG Y. Effect of manure on soil nitrogen and biomass of maize under plastic-film mulching cultivation. Chinese Journal of Soil Science. 21, $162,1990$.

11. CHEN X., GUO S., WANG J., ZHANG J. Effect of mulching cultivation with plastic film on soil microbial population and biological activity. Chinese Journal of Applied Ecology. 9, 435, 1998.

12. HOU X., WANG J., LI S. Effects of different fertilization and plastic-mulching on functional diversity of soil microbial community. Acta Ecologica Sinica. 27, 655, 2007.

13. NANNIPIERI P., ASCHER J., CECCHERINI M.T. Microbial diversity and soil functions. Eur. J. Soil. Sci. 54, 655, 2003.

14. THOMAS R.W.Y.A.S.M. Microbial nitrogen cyclesphysiology, genomics and applications. Current Opinion in Microbiology. 4, 307, 2001.

15. BERG G. Plant-microbe interactions promoting plant growth and health: perspectives for controlled use of microorganisms in agriculture. Applied Microbiology and Biotechnology. 84, 11, 2009.

16. LUGTENBERG B., KAMILOVA F. Plant-growthpromoting rhizobacteria. Annual Review of Microbiology. 63, 541-556, 2009.

17. BHAT A.K. Preserving microbial diversity of soil ecosystem: a key to sustainable productivity. International Journal of Current Microbiology and Applied Sciences. 2, 85, 2013.

18. YIN C., JONES K.L., PETERSON D.E., GARRETT K.A., HULBERT S.H., PAULITZ T.C. Members of soil bacterial communities sensitive to tillage and crop rotation. Soil Biology and Biochemistry. 42, 2111, 2010.

19. SHARMA S.K., RAMESH A., SHARMA M.P., JOSHI O.P., GOVAERTS B., STEENWERTH K.L., KARLEN D.L. Microbial community structure and diversity as indicators for evaluating soil quality. Biodiversity, Biofuels, Agroforestry and Conservation Agriculture. Springer Netherland. 317, 2011.

20. RAMIREZ K.S., LAUBER C.L., KNIGHT R., BRADFORD M.A., FIERER N. Consistent effects of nitrogen fertilization on soil bacterial communities in contrasting systems. Ecology. 91, 3463, 2010.

21. LIN Y., XUE Q., YAN X. Effects of Allelopathy of Maize and Wheat Root on Soil Microorganism under the Plastic Film Mulching Condition. Acta Agriculturae Borealioccidentalis Sinica. 19, 92, 2010.

22. NI LIJIA, LI FEI. The Asian Monograph. Mulching on soil micro-ecological environment of Zhejiang University of Technology. 39, 407, 2011.

23. GUO FAN, CHEN XI, WANG JINGKUAN. Effect of plastic film mulching on soil microflora. Journal of Soil Science. 26, 36, 1995.

24. SUN RUILIAN, ZHU LUSHENG, ZHAO BINGQIANG. Effects of long-term fertilization on soil microorganism and its role in adjusting and controlling soil fertility. Chinese Journal of Applied Ecology. 15, 1907, 2004. 
25. CHAUDHRY V., REHMAN A., MISHRA A., CHAUHAN P.S., NAUTIYAL C.S. Changes in bacterial community structure of agricultural land due to long-term organic and chemical amendments. Microbial Ecology. 64, 450, 2012.

26. SUN R., ZHANG X., GUO X., WANG D., CHU H. Bacterial diversity in soils subjected to long-term chemical fertilization can be more stably maintained with the addition of livestock manure than wheat straw. Soil Biology and Biochemistry. 88, 9, 2015.

27. UNC A., GOSS M.J. Transport of bacteria from manure and protection of water resources. Applied Soil Ecology. 25, 1,2004

28. BUCKERIDGG KM., BANERJEE S., SICILIANO SD., GROGAN P. The seasonal pattern of soil microbial community structure in mesic low arctic tundra. Soil Biology \& Biochemistry. 65, 338, 2013.

29. YAO H., BOWMAN D., SHI D. Seasonal variations of soil microbial biomass and activity in warm- and cool-season turfgrass systems. Soil Biology \& Biochemistry. 43, 1536, 2011.

30. KHALIL U.R., ZHANG Y., SHAHLA A., ZHAO J., ERINLE KO. Short Term Influence of Organic and Inorganic Fertilizer on Soil Microbial Biomass and DNA in Summer and Spring. Journal of Northeast Agricultural University. 23, 20, 2016.

31. WANG J., LIU S., LI S. Effect of long-term plastic film mulching and fertilization on inorganic $\mathrm{N}$ distribution and organic $\mathrm{N}$ mineralization in brown earth. Journal of Soil and Water Conservation. 20, 107, 2006.

32. LIANG W., LOU Y., LI Q., ZHONG S., ZHANG X., WANG J. Nematode faunal response to long-term application of $\mathrm{N}$ fertilizer and inorganic manure in northeast China. Soil Biology and Biochemistry. 41, 883, 2009.

33. LOU Y., WANG J., LIANG W. Imparts of 22-year organic and inorganic $\mathrm{N}$ managements on soil organic $\mathrm{C}$ fractions in a maize field, northeast China. Catena. 87, 386, 2011.

34. MAGOČ T., SALZBERG S.L. Fast length adjustment of short reads to improve genome assemblies. Bioinformatics. 27, 2957, 2011.

35. CAPORASO J.G., KUCZYNSKI J., STOMBAUGH J., BITTINGER K., BUSHMAN F.D., COSTELLO E.K., FIERER N., PENA A.G., GOODRICH J.K., GORDON J.I., HUTTLEY G.A., KELLEY S.T., KNIGHTS D., KOENIG J.E., LEY R.E., LOZUPONE C.A., MCDONALD D., MUEGGE B.D., PIRRUNG M., REEDER J., SEVINSKY J.R., TURNBAUGH P.J., WALTERS W.A., WIDMANN J., YATSUNENKO T., ZANEVELD J., KNIGHT R. QIIME allows analysis of high-throughput community sequencing data. Nature Methods. 7, 335, 2010.

36. WANG Q., GARRITY G.M., TIEDJE J.M., COLE J.R. Naïve Bayesian Classifier for Rapid Assignment of rRNA Sequences into the New Bacterial Taxonomy. Applied and Environmental Microbiology. 73, 5261, 2007.

37. EDGAR R.C. UCHIME improves sensitivity and speed of chimera detection. Bioinformatics. 27, 2194, 2011.

38. HAAS BRIAN J. Chimeric 16S rRNA sequence formation and detection in Sanger and 454-pyrosequenced PCR amplicons. Genome research. 21, 494, 2011.

39. EDGAR R.C. UPARSE: Highly accurate OTU sequences from microbial amplicon reads. Nature methods. 10, 996, 2013.

40. DESANTIS., TODD Z. Greengenes, a chimera-checked 16S rRNA gene database and workbench compatible with ARB. Applied and environmental microbiology. 72, 5069, 2006.
41. EDGAR R.C. MUSCLE: multiple sequence alignment with high accuracy and high throughput. Nucleic acids research. 32, 1792, 2004.

42. SCHLOSS P.D. Introducing mothur: Open-source, platform-independent, community-supported software for describing and comparing microbial communities. Applied and Environmental Microbiology. 75, 7537, 2009.

43. JIANG X.T., PENG X., DENG G.H., SHENG H.F., WANG Y., ZHOU H.W., TAM N.Y. Illumina Sequencing of 16S rRNA Tag Revealed Spatial Variations of Bacterial Communities in a Mangrove Wetland. Microbial Ecology. 66, 96, 2013

44. LUO P., HAN X., WANG Y., HAN M., SHI H., LIU N., BAI $\mathrm{H}$. Influence of long-term fertilization on soil microbial biomass, dehydrogenase activity, and bacterial and fungal community structure in a brown soil of northeast China. Annals of Microbiology. 65, 533, 2014.

45. LI J., LI Y., YANG X., ZHANG J., LIN Z., ZHAO B. Microbial community structure and functional metabolic diversity are associated with organic carbon availability in an agricultural soil. Journal of Integrative Agriculture. 14, 2500, 2015.

46. WEI D., YANG Q., ZHANG J.Z., WANG S., CHEN X.L., ZHANG X.L., LI W.Q. Bacterial community structure and diversity in a black soil as affected by long-term fertilization. Pedosphere. 18, 582, 2008.

47. HUGENHOLTZ P., GOEBEL B.M., PACE N. Impact of culture-independent studies on the emerging phylogenetic view of bacterial diversity. Journal of Bacteriology. 180, 4765, 1998.

48. CHEN Y., WEN X., SUN Y., ZHANG J., WU W., LIAO Y. Mulching practices altered soil bacterial community structure and improved orchard productivity and apple quality after five growing seasons. Scientia Horticulturae. 172, 248, 2014.

49. SAPP M., HARRISON M., HANY U., CHARLTON A., THWAITES R. Comparing the effect of digestate and chemical fertiliser on soil bacteria. Applied Soil Ecology. 86, $1,2015$.

50. JONES R.T., ROBESON M.S., LAUBER C.L., HAMADY M., KNIGHT R. A comprehensive survey of soil acidobacterial diversity using pyrosequencing and clone library analyses. ISME J. 3, 442, 2009.

51. NAETHER A., FOESEL B.U., NAEGELE V., WÜST P.K., WEINERT J., BONKOWSKI M., ALT F., OELMANN Y., POLLE A., LOHAUS G., HEMP S., HEMP A., KALKO V E.K., LINSENMAIR K.E., PFEIFFER S., RENNER S., SCHÖNING I., WEISSER W.W., WELLS K., FISCHER M., OVERMANN J., FRIEDRICH M.W. Environmental factors affect Acidobacterial communities below the subgroup level in grassland and forest soils. Appl. Environ. Microbiol. 78, 7398, 2012.

52. CEDERLUND H., WESSÉN E., ENWALL K. Soil carbon quality and nitrogen fertilization structure bacterial communities with predictable responses of major bacterial phyla. Applied Soil Ecology. 84, 62, 2014.

53. NEMERGUT D.R., TOWNSEND A.R., SATTIN S.R., FREEMAN K.R., FIERER N., NEFF J.C., BOWMAN W.D., SCHADT C.W., WEINTRAUB M.N., SCHMIDT S.K. The effects of chronic nitrogen fertilization on alpine tundra soil microbial communities: implications for carbon and nitrogen cycling. Environ. Microbiol.10, 3093, 2008.

54. DEBRUYN J.M., NIXON L.T., FAWAZ M.N., JOHNSON A.M., RADOSEVICH M. Global biogeography and quantitative seasonal dynamics of Gemmatimonadetes in soil. Appl. Environ. Microbiol. 77, 6295, 2011. 
55. LIU E.K., YAN S., MEI X.R, HE W., BING S.H., DING L., LIU Q., LIU S., FAN T. Long-term effect of chemical fertilizer, straw, and manure on soil chemical and biological properties in northwest China. Geoderma. 158, 173, 2010.

56. MASTO R.E., CHHONKAR P.K., SINGH D., PATRA A.K. SOil quality response to long-term nutrient and crop management on a semi-arid Inceptisol. Agriculture, Ecosystems and Environment. 118, 130, 2007.

57. CZARNECKI S., DÜRING R.A. Influence of long-term mineral fertilization on metal contents and properties of soil samples taken from different locations in Hesse, Germany. SOIL. 1, 23, 2015.

58. LIANG Q., CHEN H., GONG Y., FAN M., YANG H., LAL R., KUZYAKOV Y. Effects of 15 years of manure and inorganic fertilizers on soil organic carbon fractions in a wheat-maize system in the North China Plain, Nutr. Cycl. Agroecosyst. 92, 21, 2012.

59. TIAN W., WANG L., YAN L., Y K., ZHUANG K., LI G., ZHANG J., XIAO X., XI Y. Responses of microbial activity, abundance, and community in wheat soil after three years of heavy fertilization with manure-based compost and inorganic nitrogen. Agriculture Ecosystems and Environment. 213, 219, 2015.

60. HE J.Z., SHEN J.P., ZHANG L.M. Quantitative analyses of the abundance and composition of ammonia-oxidizing bacteria and ammonia-oxidizing archaea of a Chinese upland red soil under long-term fertilization practices. Environmental Microbiology. 9, 2364, 2007.

61. LAUBER C.L., HAMADY M., KNIGHT R., FIERER N. Pyrosequencing-based assessment of soil $\mathrm{pH}$ as a predictor of soil bacterial community structure at the continental scale. Applied and Environmental Microbiology. 75, 5111, 2009.

62. NICOL G.W., S LEININGER., C SCHLEPER. The influence of soil $\mathrm{pH}$ on the diversity, abundance and transcriptional activity of ammonia oxidizing archaea and bacteria. Environ Microbiol. 10, 2966, 2008.

63. LU L., JIA Z. Urease gene-containing Archaea dominate autotrophic ammonia oxidation in two acid soils. Environ. Microbiol. 15, 1795, 2013. 
